\title{
Early-Middle Frasnian (Late Devonian) carbon isotope Event in the Timan-Pechora Basin (Chernyshev Swell, Pymvashor River section, North Cis-Urals, Russia)
}

\author{
Ivan S. Kotik Andrey V. Zhuravlev Tatiana V. Maydl Dmitriy A. Bushnev Irina V. Smoleva \\ Institute of Geology of Komi Science Centre of the Ural Branch of the Russian Academy of Sciences \\ Pervomaiskaya 54, Syktyvkar 167982, Russia. Kotik E-mail: ivkotik@gmail.com
}

\begin{abstract}
Details of the Early-Middle Frasnian boundary interval of the Pymvashor River section (Timan-Pechora Basin, CisUrals, in the far north of European Russia) are revealed by biostratigraphically constrained carbonate $\left(\delta^{13} \mathrm{C}_{\text {carb }}\right)$ and organic carbon $\left(\delta^{13} \mathrm{C}_{\text {org }}\right)$ stable data. The studied interval corresponds to the lower part of the Domanik Formation, which consists of interbedded limestone and shale beds. Organic-rich black shale that lacks bioturbation and benthic organisms indicates an oxygen-depleted depositional environment. Detection of isorenieratene derivatives in organic matter indicates that anoxia was present in the photic zone during deposition. The Pymvashor River section contains $\delta^{13} \mathrm{C}_{\text {carb }}$ and $\delta^{13} \mathrm{C}_{\text {org }}$ isotope records related to the Early-Middle Frasnian isotope Event. The similarity between the Cis-Uralian (this study) and the Chinese $\delta^{13} \mathrm{C}_{\text {carb }}$ and $\delta^{13} \mathrm{C}_{\text {org }}$ oscillations, including the twostep pattern of the recorded major positive excursions, suggests a robust correlation of the Late Devonian EarlyMiddle Frasnian isotope Event and minor intra-event excursions. Magnitude of variations and values of $\delta^{13} \mathrm{C}_{\text {org }}$ and $\delta^{13} \mathrm{C}_{\text {carb }}$ in the punctata Zone in the Pymvashor River section are minor than those observed in the North American, Polish, and Chinese successions. Such difference may reflect specific variation of the local environments.
\end{abstract}

KEYWORDS Late Devonian; punctata Event; carbon isotopes; biomarkers; conodonts.

\section{INTRODUCTION}

The stratigraphic level near the Early-Middle Frasnian boundary, known as the Middlesex Event (Becker et al., 1993; Ma et al., 2006; Pisarzowska et al., 2020), is attributed to the Late Devonian global transgression equivalent to the initial phase of cycle IIc (Johnson et al., 1985). Tectonic formation of deep intracratonic basins in the Cis-Uralian region occurred in the Middle Frasnian as well. Anoxic sedimentation in these basins is known as the regional 'Domanik Crisis' (Kuzmin et al., 1997). The hypoxic Middlesex Event coincides with the start of a $\delta^{13} \mathrm{C}$ positive excursion in the latest Palmatolepis transitans Zone preceding a prominent drop in $\delta^{13} \mathrm{C}$ values near the Palmatolepis punctata-Early Palmatolepis hassi boundary (Ma et al., 2008; Pisarzowska et al., 2006, 2020; Pisarzowska and Racki, 2012; Yans et al., 2007). Significant variations in the $\delta^{13} \mathrm{C}$ values in the latest transitans-punctata time interval are known as the transitans-punctata isotope Event or Early-Middle Frasnian isotopic perturbation (Pisarzowska et al., 2020; Racki et al., 2008; Yans et al., 2007), which is distinguished in distant disparate sedimentary basins throughout the world and considered to be a reliable chemostratigraphic marker of the Early-Middle Frasnian boundary (Bai et al., 1994; Baliński, 2006; Ma et al., 2008; Pisarzowska et al., 2006, 2020; Yans et al., 2007). Detailed study of the event structure revealed a four-step positive-to-negative excursion 
pattern (Ma et al., 2008; Racki et al., 2008; Pisarzowska et al., 2006, 2020). Manifestations of the transitanspunctata isotope Event have been well studied in West and Central Europe, South China, and North America (Bai et al., 1994; Baliński, 2006; Lash, 2019; Morrow et al., 2009; Pisarzowska et al., 2006, 2020; Yans et al., 2007). However, much less is known of this event in East Europe (Soboleva et al., 2018; Zhuravlev et al., 2006).

This paper contributes to our knowledge of the regional manifestation of the transitans-punctata isotope Event in north-east Europe. We present here the results of a multidisciplinary research in the Pymvashor River section located in the north-eastern part of the TimanPechora Basin (North Cis-Urals). The chronostratigraphic framework of this study follows the Subcommission on Devonian Stratigraphy propositions (see Ziegler and Sandberg, 2001).

\section{GEOLOGICAL AND PALEOGEOGRAPHIC SETTING}

The study area is located in the Timan-Pechora Basin in the north-east of the East European Craton in Russia (Fig. 1A, B, C). The object of our research was the Upper Devonian (Frasnian) deposits, which are widespread in the Timan-Pechora Basin (Fig. 1D, E). Upper Devonian deposits crop out at the Timan Ridge, Chernyshev Swell and Polar and Subpolar Urals in the Timan-North Ural region (Belyaeva and Ivanov, 2000; Tsyganko, 2011; Fig. 1C).

The studied Frasnian section is located in the northern area of the Chernyshev Swell, a linear structure located in the north-east of the Timan-Pechora Basin (Fig. 1B, C). The swell is interpreted to have formed as a result of disruption by an Upper Ordovician evaporite detachment fault in the final stage of the Uralian orogeny during the Jurassic (Timonin, 1998; Yudin, 1994). The western boundary of the Chernyshev Swell is a detachment fault and its eastern boundary is a back-thrust fault that forms a pop-up structure (Fig. 1C, E). Several fold-thrust structures that affected the Silurian-Triassic sequences (Belonin et al., 2004) are identified as integral structural components of the swell.

The Timan-Pechora Basin (Fig. 1D, E) developed during Late Devonian time as a passive shelf margin in the northeast edge of the Laurussian continent at the front of the Uralian Strait (Timonin, 1998; Fig. 1D). The great diversity of Late Devonian facies in the basin is attributed to the presence of a complex relief and local tectonics (Belyaeva et al., 1998; Parmusina, 2007). The following facies belts can be observed from west to east: coastal plain, shallow shelf, reef, deep water outer shelf basin, and isolated carbonate platform (Gruzdev, 2017; Nikonov et al., 2000; Parmusina, 2007; Fig. 1D). The sequences accumulated in deep water environments belong to the Domanik Formation, named after the Domanik Stream in South Timan (Belyaeva and Ivanov, 2000). The Domanik Formation comprises Middle Frasnian organic-rich carbonate-clay-siliceous facies that were deposited in deep-water shelf basin (Fig. 1D).

The development of anoxic bottom conditions during deposition of the Domanik Formation was proposed on the base of lithological, paleontological, and geochemical investigations, including those of Bushnev et al. (2016) and Kuzmin et al. (1997). Most studies of the Upper Devonian deposits of the Timan-Pechora Basin have relied upon core analysis.

The studied section is located within the Talbey block, where Frasnian deposits are exposed on the left bank of the Pymvashor River at the left tributary of the Adzva River (Fig. 1C). The Frasnian deposits of the Pymvashor River section consist of deep-water facies (i.e. the Domanik Formation).

\section{METHODS}

\section{Organic carbon content $\left(\mathrm{C}_{\text {org }}\right)$}

Organic carbon was determined by treating dried samples with $15 \%$ solution of $\mathrm{HCl}$ to remove carbonate prior to instrument analysis. $\mathrm{C}_{\text {org }}$ content was measured on an AN-7529 rapid carbon analyzer. Glucose and standard steel were used as standards. Measured values are reported as percent relative to whole rock.

\section{Soluble organic matter composition}

Bitumen was extracted from 50-100g of powdered rock samples using a Soxhlet apparatus for $48 \mathrm{~h}$ with chloroform. The extracted bitumen was treated with elemental copper during extraction of elemental sulphur. The extracted bitumen was separated into aliphatic and aromatic fractions by liquid chromatography on a silica-gel column.

Gas Chromatography (GC) and Gas ChromatographyMass Spectrometry (GC-MS) were used to determine the abundance of selected families of molecular biomarkers (i.e. $n$-alkanes and acyclic isoprenoids, terpanes, and steranes) in saturated bitumen fractions from six selected samples. Aromatic fractions were analysed using GC-MS. Analyses of $n$-alkanes and isoprenoids were carried out using a Crystal 2000M GC System with a DB-1 column. The GC-MS investigations were performed using Shimadzu QP2010 Ultra instrument equipped with a DB-5 column. Details are described in Bushnev et al. (2016, 2017a). 

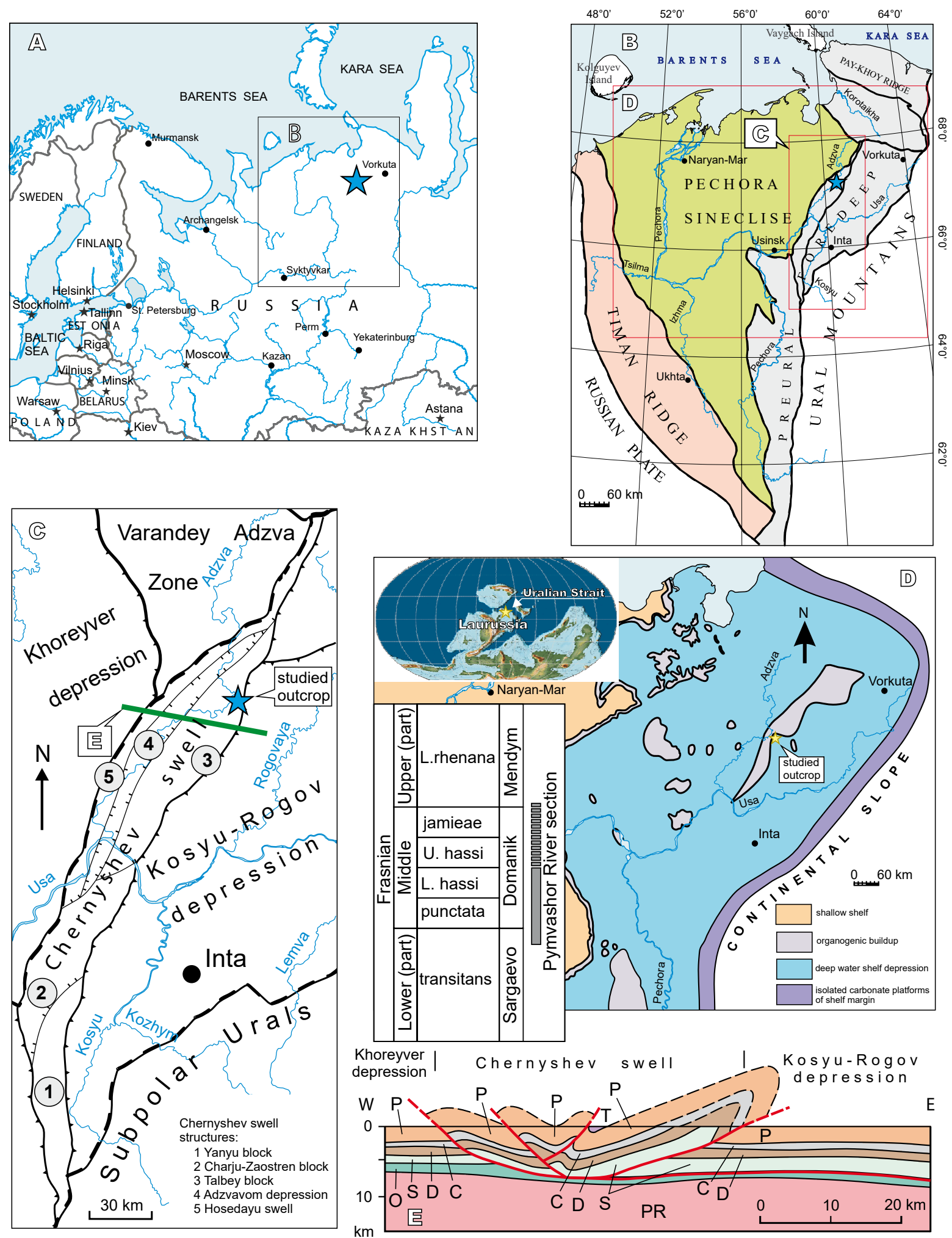

FIGURE 1. A) Location of the Timan-Pechora Basin (B) in Russia. Study area indicated by blue star. B) The Timan-Pechora Basin with location of figures C and D. C) Structural sketch (modified from Belonin et al., 2004) showing the major morphostructural features of the study area (Chernyshev Swell and related units). The location of the studied outcrop and the cross-section in E are also shown. D) Middle Frasnian (Upper Devonian) palaeogeography and palaeoenvironmental setting of the studied Pymvashor River section in the north of the Timan-Pechora Basin (based on Nikonov et al., 2000; Parmusina, 2007). See B for location. E) Geological cross-section showing the Chernyshev Swell pop-up structure and the overall stratigraphy of the region (modified from Yudin, 1994). PR: Precambrian; O: Ordovician; S: Silurian; D: Devonian; C: Carboniferous; P: Permian. 


\section{Stable isotopes}

\section{Organic carbon stable isotope composition}

Organic matter was extracted from limestones by dissolution of carbonates in $\mathrm{HCl}$ and combusted in the presence of oxygen at $900^{\circ} \mathrm{C}$. Carbon isotope values were measured with a DELTA V Advantage mass spectrometer equipped with a Thermo Electron Continuous Flow Interface (ConFlo III) and Element Analyzer (Flash EA 1112). International standard USGS-40 (L-Glutamic acid) and internal standard Acetanilide $\left(\mathrm{C}_{8} \mathrm{H}_{9} \mathrm{NO}\right)$ were used. The precision of the $\delta^{13} \mathrm{C}_{\text {org }}$ value is $\pm 0.15 \%$ and $\delta^{13} \mathrm{C}_{\text {org }}$ values are reported relative to the VPDB (Vienna Pee Dee Belemnite) standard.

\section{Isotope composition of organic carbon of conodont elements}

Preparation of samples for isotopic analysis of organic carbon from conodonts followed standard procedures using $10 \%$ acetic acid. Good conodont preservation and a moderate Conodont Alteration Index (CAI lower than 3) favor near-primary isotopic composition of organic matter (Zhuravlev and Smoleva, 2018; Zhuravlev, 2020).

Conodont elements of Mesotaxis asymmetricus were used to study the carbon isotope composition of conodont organic matter. Separated conodont elements were washed with ethanol and distilled water. The samples were analyzed for carbon isotope values on a DELTA V Advantage mass spectrometer equipped with a Thermo Electron Continuous Flow Interface (ConFlo III) and Element Analyzer (Flash EA 1112). International standard USGS-40 (L-Glutamic acid) was used. The precision of the $\delta^{13} \mathrm{C}_{\text {org-con }}$ value is $\pm 0.15 \%$, and measured values are reported relative to the VPDB standard.

\section{Carbonate carbon and oxygen isotope composition}

Samples for carbonate carbon and oxygen isotope analysis were drilled from fresh surfaces using microdrilling equipment with steel bits. The samples mainly represent the micritic part of the rock. Carbonate carbon and oxygen isotope compositions were obtained on a DELTA V Advantage mass spectrometer with sample preparation on a Gas Bench II line using standard methods. The $\delta^{13} \mathrm{C}_{\text {carb }}$ values were reported relative to the VPDB standard, and $\delta^{18} \mathrm{O}_{\text {carb }}$ values are relative to the SMOW (Standard Mean Ocean Water). The precision of the $\delta^{13} \mathrm{C}_{\text {carb }}$ value is $\pm 0.04 \%$, and that of the $\delta^{18} \mathrm{O}_{\text {carb }}$ value is $\pm 0.06 \%$.

Isotope analyses were performed at the CKP "Geonauka" of Institute of Geology Komi SC UrB RAS
(Syktyvkar, Russia). The reliability of the isotope record was enhanced by application of several screening tests to the bulk-carbonate isotope data (Brand et al., 2011):

I) Visual examination. Fresh surfaces of samples were drilled to collect fresh carbonate powder for analysis.

II) Optical examination in thin section. Samples demonstrating significant re-crystallisation of the micritic component were avoided.

III) Stable isotope distribution. A synoptic screening diagram based on Huck et al. (2017), Immenhauser et al. (2003), Lohmann (1988) and Chen et al. (2016) was used (Fig. 2).

IV) Total organic content. High content of organic carbon in carbonates $\left(>1.7 \%\right.$ that corresponds to $\mathrm{C}_{\text {org }}$ l $\mathrm{C}_{\text {carb }}$ ratio less than $1 / 7$ ) may lead to incorporation into carbonates of ${ }^{12} \mathrm{C}$ derived from oxidised organic matter (Scholle and Arthur, 1980). This process potentially decreases the $\delta^{13} \mathrm{C}_{\text {carb }}$ value. The carbonate samples demonstrating high content of organic carbon were used with care.

Samples passing at least two of tests 2,3 and 4 were considered as providing reliable isotope signal.

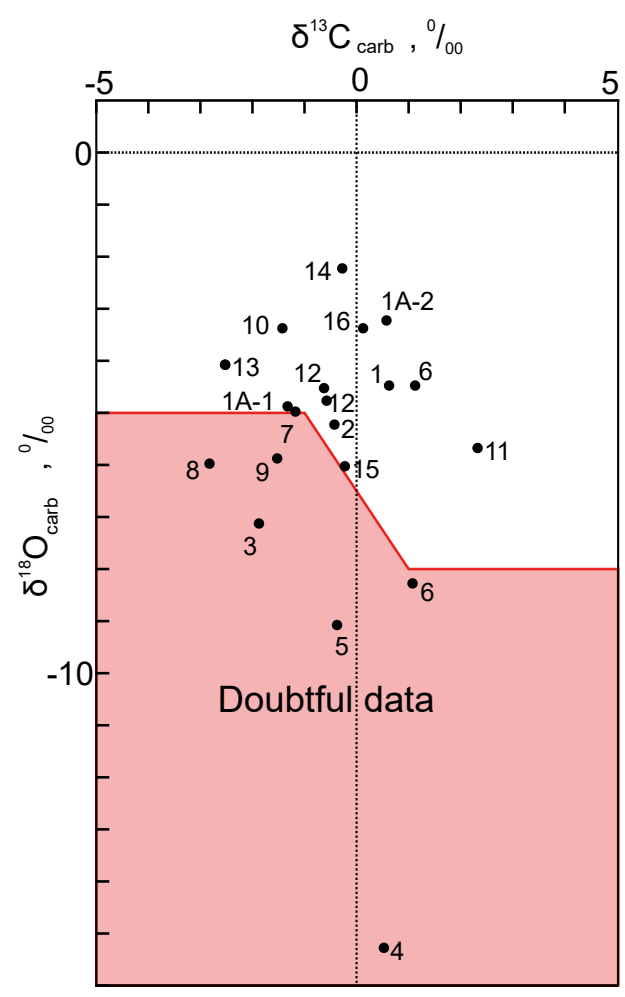

FIGURE 2. Bivariate plot of the bulk carbonate $\delta^{13} \mathrm{C}$ carb and $\delta^{18} \mathrm{O}$ carb from the Pymvashor River section (see further explanation in the main text). 


\section{STRATIGRAPHY}

The first lithological and stratigraphic description of the studied section was carried out by A.I. Pershina (1962). Pershina (1962) based on the study of brachiopods, cephalopods, bivalves, ostracods, trilobites, and foraminifers proposed a Domanik-Mendymian age (punctata Lower rhenana conodont zones) for the exposed deposits. V.V. Kachmashev led a geological investigation of the study area in 1984-1988 (unpublished technical report, 1988) that included a paleontological-biostratigraphic sampling. Two conodont samples collected from the upper part of the Pymvashor River section during Kachmashev's work confirmed the Mendymian age (ca. Lower rhenana Zone). We studied the Frasnian deposits exposed along the Pymvashor River in 2017 in order to improve the biostratigraphic and lithofacies characterisation of the section and to obtain isotope and geochemical data for the first time.

\section{Lithostratigraphy and facies description}

The Frasnian section of the Domanik Formation is $10.7 \mathrm{~m}$ thick and mainly constituted by interbedded black shale and dark-grey, micro- to finely-crystalline limestone beds. Lithology changes within this unit include the occurrence of diverse proportions of shale and limestone beds. Scarce chert layers also occur (Fig. 3). Limestone layers range from a few (2-5) to tens $(15-20) \mathrm{cm}$ in thickness. The diverse limestone microfacies are shown in Figure 4.

The macroscopic lithological characteristics and the microfacies analysis enable one to split the Frasnian succession exposed in the Pymvashor River section from bottom to top, in successive beds and bed sets (Fig. 3):

1A: $0-1.0 \mathrm{~m}$ black shales interbedded with thin (up to $10 \mathrm{~cm}$ thick) dark-grey, finely-crystalline, radiolarian wackestone;

1: $1.0-1.4 \mathrm{~m}$ interbedded black shales (Fig. $4 \mathrm{~F}$ ) and dark-grey, finely-crystalline, tentaculite packstonewackestone (Fig. 4A). Beds are approximately $5 \mathrm{~cm}$ in thickness;

2: 1.4-1.7m dark-grey, finely-crystalline, detrital wackestone containing a 5 -cm-thick layer of black shale in the middle of the bed;

3: 1.7-3.0m interbedded thin beds of dark-grey limestone, black shale (Fig. 4H), and black tentaculite bearing chert (1-7cm thick) (Fig. 4G);

4: $3.0-3.3 \mathrm{~m}$ dark-grey, finely-crystalline, tentaculite packstone-grainstone (Fig. 4B);

5: $3.3-3.8 \mathrm{~m}$ interbedded black shales and dark-grey, finely-crystalline limestones. Beds are $\sim 2-3 \mathrm{~cm}$ in thickness;
6: $3.8-4.8 \mathrm{~m}$ dark-grey, finely-crystalline, tentaculiteradiolarian wackestone-packstones interbedded with thin $(2 \mathrm{~cm})$ black shale layers;

7: 4.8-5.8m interbedded dark-grey, finely-crystalline limestone and tentaculite-rich black shale (Fig. 4I);

8: $5.8-6.3 \mathrm{~m}$ dark-grey, microcrystalline, tentaculite wackestone-packstone bed with a 3 -cm-thick black shale in the middle of the bed (Fig. 4C);

9: 6.3-6.9m thin-bedded, brownish-grey, finely-crystalline, tentaculite mudstone-wackestone;

10: $6.9-8.4 \mathrm{~m}$ interbedded dark-grey, finely-crystalline, tentaculite mudstone-wackestones (Fig. 4D) and black shales containing tentaculites;

11: 8.4-9.5m dark-grey, finely-crystalline, detrital mudstone beds interbedded with black shales;

12: $9.5-10.7 \mathrm{~m}$ grey, finely-crystalline, mudstonewackestone, containing radiolarians, tentaculites, rare brachiopods, and ammonoids (Fig. 4E).

\section{Conodont biostratigraphy}

Ten of the eleven samples collected for conodont analysis yielded conodonts. Each sample weighted 0.5 to $1.0 \mathrm{~kg}$. The processing of samples followed standard procedure using $10 \%$ acetic acid.

Conodont associations in the lower part of the section are dominated by Mesotaxis (beds 1A-2) and Polygnathus (beds 4-6) (Table 1). In the upper part of the section, conodont associations are dominated by Palmatolepis (beds 8-9 and bed 12) and Polygnathus (beds 10-11) (Table 1). Characteristic conodont species are illustrated in Figure 5. Conodont associations found in the productive conodont samples allowed us to distinguish two conodont zones and an unzoned interval in the lowermost part of the section.

The lowermost part of the section (bed 1A) contains Frasnian conodonts of wide stratigraphic range (Table 1). The presence of Mesotaxis bogoslovskyi OVNATANOVA AND KUZMIN suggests an Early-Middle Frasnian (transitanspunctata zones) age for this part of the section. The first occurrence of Palmatolepis punctata in bed 1 marks the base of the punctata Zone (Table 1; Fig. 3). The lower part of the zone contains representatives of Mesotaxis, which are absent from the base of bed 9. The upper part of the zone is characterized by taxonomically poor conodont associations dominated by Polygnathus. The entry of Polygnathus uchtensis in bed 6 allowed us to identify the upper part of the punctata Zone.

The first occurrence of Palmatolepis hassi in association with Lagovina nonaginta in the upper part of bed 12 marks the base of the Lower hassi Zone. Early entry of Palmatolepis ljaschenkoae OVNATANOVA in sample 14 

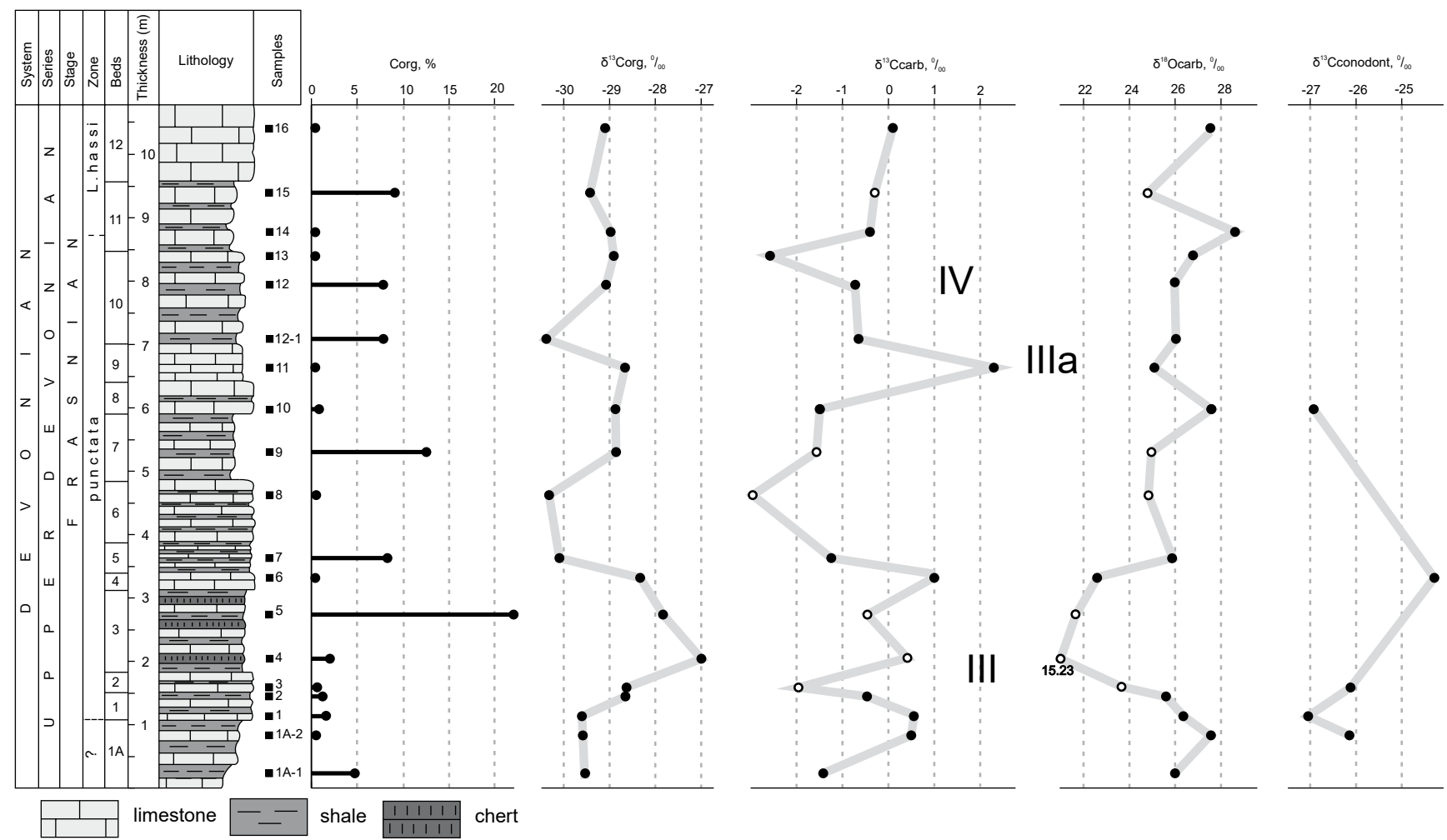

FIGURE 3. Stable carbon and oxygen isotope geochemistry of the Middle Frasnian in the the Pymvashor River section. White dots on graphs mark unreliable discarded data. Labels III and IV designate the carbon isotopic events distinguished by Pisarzowska et al. (2006) in the Holy Cross Mountains. Label Illa emphasises the minor isotope excursion observed in Southern China and the Pymvashor River sequences.

(bed 11) suggests the likelihood of a lower position of the Lower hassi Zone, probably near the base of bed 11 (Table 1; Fig. 3).

The reported conodont data suggests that the sequence studied comprises the entire Middle Frasnian punctata Zone. It appears, however, that the first occurrence of zonal index species (Palmatolepis punctata and Palmatolepis hassi) is delayed in the succession.

\section{ORGANIC GEOCHEMISTRY RESULTS}

\section{$\mathrm{C}_{\text {org }}$ content}

$\mathrm{C}_{\text {org }}$ content of analysed samples ranges from $0.2 \%$ to 22\% (Fig. 3; Table 2) depending on sample lithology. The greatest $\mathrm{C}_{\text {org }}$ values are observed in shales, varying from $4.8 \%$ to $22 \%$. Limestone samples are characterised by low $\mathrm{C}_{\text {org }}$ content $(0.2 \%$ and $1.1 \%)$, and the single chert sample analysed contains $1.9 \% \mathrm{C}_{\text {org. }}$.

\section{n-Alkanes and isoprenoids}

Geochemical analysis conducted in a previous study (Kotik et al., 2019) of six samples from the studied succession indicate that samples of high (shale) and low (limestone, chert) $\mathrm{C}_{\text {org }}$ content differ in the distribution of hydrocarbon biomarkers. The $n$-alkanes exhibit unimodal distribution in samples 7, 9, 12 (shales) and 13 (limestone), with a maximum distribution in the range of $\mathrm{C}_{13}-\mathrm{C}_{18}$ (Fig. 6A). The distribution of $n$-alkanes in limestone (sample 8) and chert (sample 4 ) are characterised by a wide maximum, ranging from $\mathrm{C}_{16}$ to $\mathrm{C}_{24}$ (Fig. 6B). Pristane/phytane (Pr/Ph) ratios of all samples fall into a relatively narrow range from 1.10 to 1.91 , and isoprenoid $/ n$-alkane ratios range from $0.45-1.03$ for $\mathrm{Pr} / n-\mathrm{C}_{17}$ and $0.32-0.80$ for $\mathrm{Ph} / n-\mathrm{C}_{18}$ (Table 3).

\section{Steranes and terpanes}

All samples analyzed for this study display a similar distribution of regular steranes (Fig. 7A). The relative percentages of $\mathrm{C}_{27}, \mathrm{C}_{28}$, and $\mathrm{C}_{29}$ steranes (Table 3) indicate that the $\mathrm{C}_{29}$ homologues predominate in all samples, followed by the $\mathrm{C}_{27}$ and $\mathrm{C}_{28}$ steranes. Concentrations of diasteranes are highest in limestone and chert samples. The $\mathrm{C}_{27}$ diasterane/regular sterane ratio in limestone and chert is $0.4-0.7$, but in shale it varies from 0.3-0.4 (Table 3 ). The relative amount of diasteranes compared to regular steranes depends on both lithology and thermal maturity of the deposits (Waples and Michihara, 1991). In our 

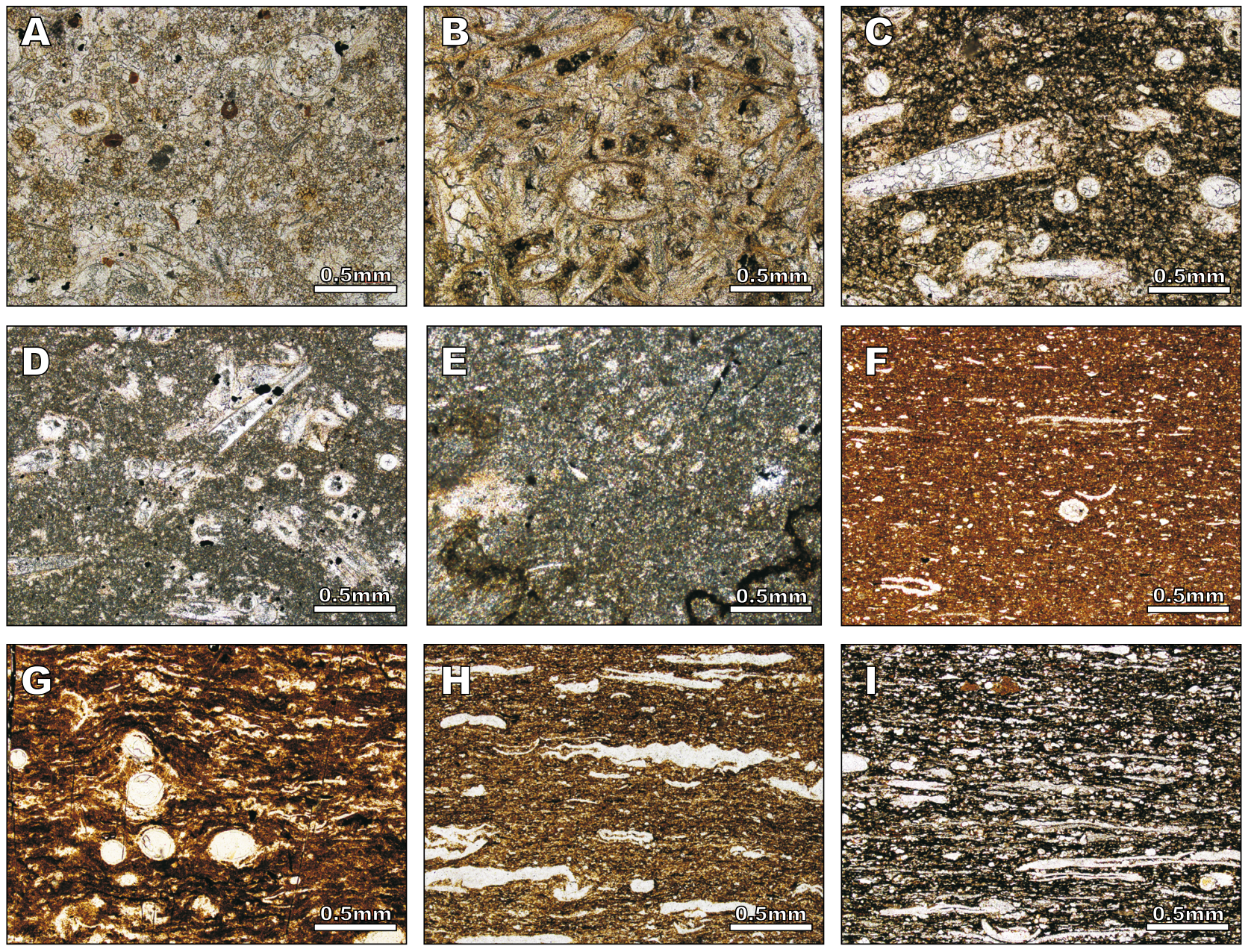

FIGURE 4. Microfacies of the Frasnian succession. A) Tentaculite packstone-wackestone, sample 1. B) Tentaculite packstone-grainstone, sample 6. C) Tentaculite wackestone-packstone, sample 10. D) Tentaculite mudstone-wackestones, sample 13. E) Bioclastic mudstone-wackestone, sample 16. F) Shale, sample 2. G) Tentaculite and radiolarian chert, sample 4. H) Shale with rare tentaculites, sample 5. I) Tentaculite shale, sample 9.

case, varying diasterane/regular sterane ratios reflect a dependence on lithology because all samples have a similar level of maturity $\left(\mathrm{R}_{\mathrm{o}}=0.6-0.75 \%\right)$. Evaluation of the thermal maturity of the studied succession was addressed earlier (Kotik et al., 2019). Among the hopanes, $\mathrm{C}_{29}$ and $\mathrm{C}_{30}$ are predominant compounds in all samples. The clear predominance of $\mathrm{C}_{31}$ hopanes among homohopanes $\mathrm{C}_{31}$ $\mathrm{C}_{35}$ is obvious from the mass chromatograms ( $\mathrm{m} / \mathrm{z} 191$, Fig. 7B).

\section{Aromatic hydrocarbons}

Analysis of the aromatic fraction of the bitumen from the Pymvashor River section reveals the presence of isorenieratane and paleorenieratane derivatives (French et al., 2015), mainly represented by monoaromatic derivatives of aryl carotenoids (Fig. 8). The content in the aromatic fraction of bitumen decreases in the series of samples as follows: $9>12>7>>4$. The content of 2,3,6-trimethyl aryl isoprenoids exceeds that of the 3,4,5-trimethyl derivatives, as noted from analysis of samples from other sections of the Domanik Formation in the Timan-Pechora Basin (Bushnev et al., 2016, 2017b).

\section{STABLE ISOTOPE RESULTS}

\section{Carbonate isotope composition}

The original carbon and oxygen isotope compositions were screened as described earlier in this paper. Samples $1 \mathrm{~A}-2,3,8,10$, and 16 contain traces of recrystallized micritic cement. Sample 4 appears to have experienced strong silicification. Such diagenetic processes can result in reduced $\delta^{13} \mathrm{C}_{\text {carb }}$ values. The low organic carbon content of carbonates (less than $1.7 \%$, that corresponds to a $\mathrm{C}_{\text {org }} / \mathrm{C}_{\text {carb }}$ ratio less than $1 / 7$ ) may suggests an insignificant contribution of ${ }^{12} \mathrm{C}$ derived from oxidized organic matter (Scholle and Arthur, 1980). Samples 4, $5,7,9,12-1,12$, and 15 contain $1.9 \%$ up to $22 \% \mathrm{C}_{\text {org }}$ 
(Table 2) and likely demonstrate depleted $\delta^{13} \mathrm{C}_{\text {carb }}$ values. The lack of covariance of $\mathrm{C}_{\text {org }}$ and $\delta^{13} \mathrm{C}_{\text {carb }}$ values of the Pymvashor River section sample suite $(R=0.10)$ suggests that pore-water conditions exerted minimal control of $\delta^{13} C_{\text {carb }}$ values. Carbon and oxygen isotope distribution on a synoptic screening diagram (Fig. 2) suggests modification of the isotope composition of samples 3 , 4, 5, 6, 8, 9 and 15. Thus, samples 3, 4, 5, 8, 9 and 15 show a set of features (combination any two features out of recrystallized micritic cement, high organic carbon content, position on a screening diagram) suggesting unreliable isotope signal (Fig. 3).

TABLE 1. Conodont distribution in the Pymvashor River section

\begin{tabular}{|c|c|c|c|c|c|c|c|c|c|c|}
\hline Zone & $?$ & \multicolumn{7}{|c|}{ punctata } & \multicolumn{2}{|c|}{ L. hassi } \\
\hline TaxalSamples & $1 \mathrm{~A}-2$ & 1 & 3 & 6 & 8 & 10 & 11 & 13 & 14 & 16 \\
\hline Mesotaxis bogoslovskyi & 1 & 3 & & & 1 & & & & & \\
\hline Mesotaxis asymmetricus & 2 & 3 & 4 & 2 & & 2 & & & & \\
\hline Lagovina sp. & 1 & & & & & & & & & \\
\hline Pandorinellina insita & & 1 & & & & & & & & \\
\hline Palmatolepis sp. & & 2 & & & 1 & 2 & 1 & & & 12 \\
\hline Palmatolepis punctata & & 1 & & 1 & & & & & 1 & \\
\hline Mesotaxis falsiovalis & & 4 & & 4 & & 1 & & & & \\
\hline Ozarkodina trepta & & 1 & 1 & & & & & & & \\
\hline Mesotaxis sp. & & & 2 & 2 & & & & & & \\
\hline Polygnathus sp. & & & & 6 & & 2 & & & 5 & 2 \\
\hline Polygnathus pseudoxylus & & & & 1 & & & & & & 4 \\
\hline Polygnathus aequalis & & & & 4 & & & & & & \\
\hline Klapperina ovalis & & & & 1 & & & & & & \\
\hline Palmatolepis triquetra & & & & 1 & & & & & & \\
\hline Polygnathus uchtensis & & & & & 2 & 1 & & & & \\
\hline Polygnathus decorosus & & & & & 1 & 1 & & 1 & 3 & 1 \\
\hline Icriodus symmetricus & & & & & 1 & & & & & \\
\hline Palmatolepis gutta & & & & & & 2 & 6 & & & \\
\hline Ligonodina sp. & & & & & & 2 & & & & \\
\hline Ancyrognathus sp. & & & & & & 1 & & & & \\
\hline Polygnathus timanicus & & & & & & & 2 & & & \\
\hline Ligonodina pectinata & & & & & & & 1 & & & \\
\hline $\begin{array}{l}\text { Youngquistognathus } \\
\text { angustidiscus } \\
\text { Icriodus alternatus }\end{array}$ & & & & & & & & & $\begin{array}{l}1 \\
1\end{array}$ & \\
\hline Palmatolepis ljaschenkoae & & & & & & & & & 1 & 2 \\
\hline Palmatolepis hassi & & & & & & & & & & 13 \\
\hline Ancyrognathus seddoni & & & & & & & & & & 1 \\
\hline Lagovina nonaginta & & & & & & & & & & 4 \\
\hline P2 elements & & 5 & 2 & & & 2 & 2 & & 3 & 3 \\
\hline M elements & & 3 & 1 & & & 1 & 1 & & 2 & 5 \\
\hline S elements & 3 & 5 & 6 & & 1 & 3 & 3 & 2 & 4 & 10 \\
\hline fragments & 1 & 9 & 5 & & 5 & 2 & 9 & 2 & 5 & 17 \\
\hline Polygnathus & 0 & 0 & 0 & 11 & 3 & 4 & 2 & 1 & 9 & 7 \\
\hline Mesotaxis & 3 & 10 & 6 & 8 & 1 & 3 & 0 & 0 & 0 & 0 \\
\hline Palmatolepis & 0 & 3 & 0 & 2 & 1 & 4 & 7 & 0 & 2 & 27 \\
\hline Icriodus & 0 & 0 & 0 & 0 & 1 & 0 & 0 & 0 & 1 & 0 \\
\hline
\end{tabular}



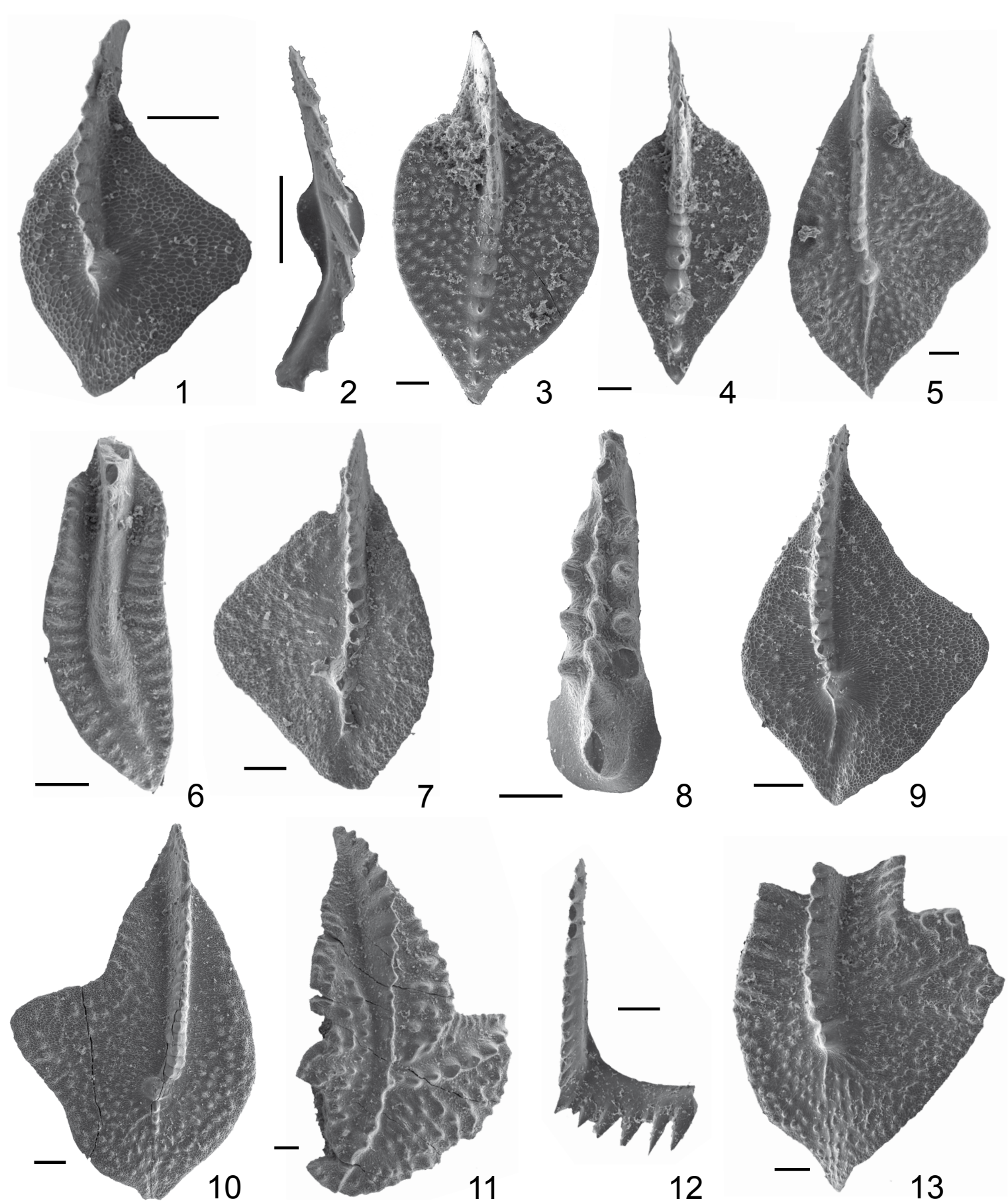

FIGURE 5. Frasnian conodonts from the Pymvashor River section. 1: Palmatolepis punctata (HINDE), sample 1. 2: Ozarkodina trepta (zIGLER), sample 1. 3: Mesotaxis asymmetricus (BISCHOFF ET ZIGLER), sample 1. 4: Mesotaxis bogoslovskyi otVNATANova et KUZmin, sample 1-2. 5: Palmatolepis punctata (HINDE), sample 6. 6: Polygnathus aequalis KLAPPER ET LANE, sample 6. 7: Palmatolepis triquetra KUZMIN, sample 6. 8: Icriodus symmetricus BRANSON ET MEHL, sample 8. 9: Palmatolepis gutta KUZMIN, sample 11. 10: Palmatolepis hassi MULLER ET MULLER, sample 16. 11: Ancyrognathus seddoni ZIGLER ET SANDBERG, sample 16. 12: Lagovina nonaginta (KLAPPER, KUZMIN ET OTVNATANOVA), sample 16. 13: Palmatolepis ljaschenkoae otvNATANOVA, sample 16. Scale bar is $0.1 \mathrm{~mm}$.

The following trends are observed in the $\delta^{13} \mathrm{C}_{\text {carb }}$ record (Fig. 3): an increase from $-1.4 \%$ to $1.1 \%$ through the lower part of the punctata Zone, followed by a negative shift of $-1.5 \%$ in beds $5-8$ (middle part of the punctata Zone). A strong positive excursion in the upper part of the punctata Zone (bed 9) is represented by a single sample with a $\delta^{13} \mathrm{C}_{\text {carb }}$ value of $2.3 \%$. Overlying deposits spanning the uppermost part of the punctata Zone and lower part of the 
TABLE 2. Isotope composition of studied samples from the Pymvashor River section

\begin{tabular}{ccccccc}
\hline Sample & Corg $\%$ & $\begin{array}{c}\delta^{13} \mathrm{C}_{\text {carb }} \\
\mathrm{PDB} \%\end{array}$ & $\begin{array}{c}\delta^{18} \mathrm{O}_{\text {carb }} \\
\text { SMOW } \%\end{array}$ & $\begin{array}{c}\delta^{13} \mathrm{C}_{\text {org }} \\
\mathrm{PDB} \%\end{array}$ & $\begin{array}{c}\delta^{13} \mathrm{C}_{\text {org-con }} \\
\mathrm{PDB} \%\end{array}$ & $\begin{array}{c}\text { Screening } \\
\text { tests }\end{array}$ \\
\hline 16 & 0.3 & 0.1 & 27.5 & -29.2 & $\mathrm{n} / \mathrm{a}$ & passed \\
15 & 8.9 & -0.3 & 24.8 & -29.4 & $\mathrm{n} / \mathrm{a}$ & not passed \\
14 & 0.3 & -0.4 & 28.7 & -29.0 & $\mathrm{n} / \mathrm{a}$ & passed \\
13 & 0.2 & -2.6 & 26.8 & -28.9 & $\mathrm{n} / \mathrm{a}$ & passed \\
12 & 7.7 & -0.7 & 26.0 & -29.1 & $\mathrm{n} / \mathrm{a}$ & passed \\
$12-1$ & 8.8 & -0.7 & 26.3 & -30.3 & $\mathrm{n} / \mathrm{a}$ & passed \\
11 & 0.2 & 2.3 & 25.1 & -28.7 & $\mathrm{n} / \mathrm{a}$ & passed \\
10 & 0.8 & -1.5 & 27.5 & -28.8 & -26.9 & passed \\
9 & 12.4 & -1.6 & 24.9 & -28.8 & $\mathrm{n} / \mathrm{a}$ & not passed \\
8 & 0.6 & -2.9 & 24.8 & -30.3 & $\mathrm{n} / \mathrm{a}$ & not passed \\
7 & 8.2 & -1.2 & 25.8 & -30.1 & $\mathrm{n} / \mathrm{a}$ & passed \\
6 & 0.3 & 1.1 & 26.4 & -28.3 & -24.3 & passed \\
6 & 0.3 & 1.0 & 22.4 & -28.3 & $\mathrm{n} / \mathrm{a}$ & passed \\
5 & 22 & -0.4 & 21.6 & -27.8 & $\mathrm{n} / \mathrm{a}$ & not passed \\
4 & 1.9 & 0.4 & 15.2 & -27.0 & $\mathrm{n} / \mathrm{a}$ & not passed \\
3 & 0.7 & -2.0 & 23.7 & -28.7 & $\mathrm{n} / \mathrm{a}$ & not passed \\
2 & 2.6 & -0.5 & 25.6 & -28.7 & $\mathrm{n} / \mathrm{a}$ & passed \\
1 & 1.1 & 0.5 & 26.4 & -29.6 & -27.0 & passed \\
$1 \mathrm{~A}-2$ & 0.6 & 0.5 & 27.6 & -29.6 & -26.2 & passed \\
$1 \mathrm{~A}-1$ & 4.8 & -1.4 & 25.9 & -29.5 & $\mathrm{n} / \mathrm{a}$ & passed \\
\hline
\end{tabular}

Lower hassi Zone (beds 10-12) display modestly depleted $\delta^{13} \mathrm{C}_{\text {carb }}$ values of $\sim-0.7 \%$.

\section{Organic matter isotope composition}

$\delta^{13} \mathrm{C}_{\text {org }}$ values of bulk organic matter show fluctuations around $-29 \%$ (Fig. 3). $\delta^{13} \mathrm{C}_{\text {org }}$ values are greatest in the lower part of the punctata Zone, with values as high as $-27 \%$ o at bed 3. This positive excursion coincides with a positive excursion in $\delta^{13} \mathrm{C}_{\text {carb }}$. Negative $\delta^{13} \mathrm{C}_{\text {org }}$ excursions in samples 7 and 8 roughly correspond to the beginning of the negative excursion in the carbonate carbon isotope composition. The mean $\delta^{13} \mathrm{C}_{\text {org }}$ value is $-29 \%$ with a standard deviation of 0.8 .

\section{Isotope composition of conodont organic matter}

Variations in isotope composition of conodont organic matter $\left(\delta^{13} \mathrm{C}_{\text {org-con }}\right)$ of the conodont species Mesotaxis asymmetricus of the lower part of the succession that spans stratigraphic range of this species were evaluated.
Low $\delta^{13} \mathrm{C}_{\text {org-con }}$ values ( $-26 \%$ to $-27 \%$ ) are characteristic of the lower part of the punctata Zone, excluding the positive excursion corresponding to the upper part of the main positive shift in $\delta^{13} \mathrm{C}_{\text {carb }}$ (Fig. 3). The mean value of $\delta^{13} \mathrm{C}_{\text {org-con, }}-25.9 \%$, is comparable with that documented from the Late Devonian-Mississippian conodonts (-25.3\%o with a standard deviation of 2.56; Zhuravlev et al., 2020). Differences between $\delta^{13} \mathrm{C}_{\text {org-con }}$ values and $\delta^{13} \mathrm{C}_{\text {org }}$ values range from $1.9 \%$ up to $4.1 \%$ and display a negative correlation with $\mathrm{C}_{\text {org }}$ content $(\mathrm{R}=-0.82)$. At the same time $\delta^{13} \mathrm{C}_{\text {org-con }}$ and $\mathrm{C}_{\text {org }}$ values exhibit a clear negative correlation $(\mathrm{R}=-0.91)$. These correlations may be attributed to trophic relations of conodonts (Zhuravlev, 2020). The carbon isotope composition of conodont organic matter probably was controlled by the isotope composition of conodont diet, represented by phyto- and zooplankton (Zhuravlev, 2020). Changes in the nutrition caused variations in the $\delta^{13} \mathrm{C}_{\text {org-con }}$ : an increase in the phytoplankton portion in the diet led to a decrease of $\delta^{13} \mathrm{C}_{\text {org-con }}$ and vice versa. Also, phytoplankton bloom and subsequent eutrophication led to $\mathrm{C}_{\mathrm{org}}$ increase in sediment. The eutrophication probably provoked shortening 


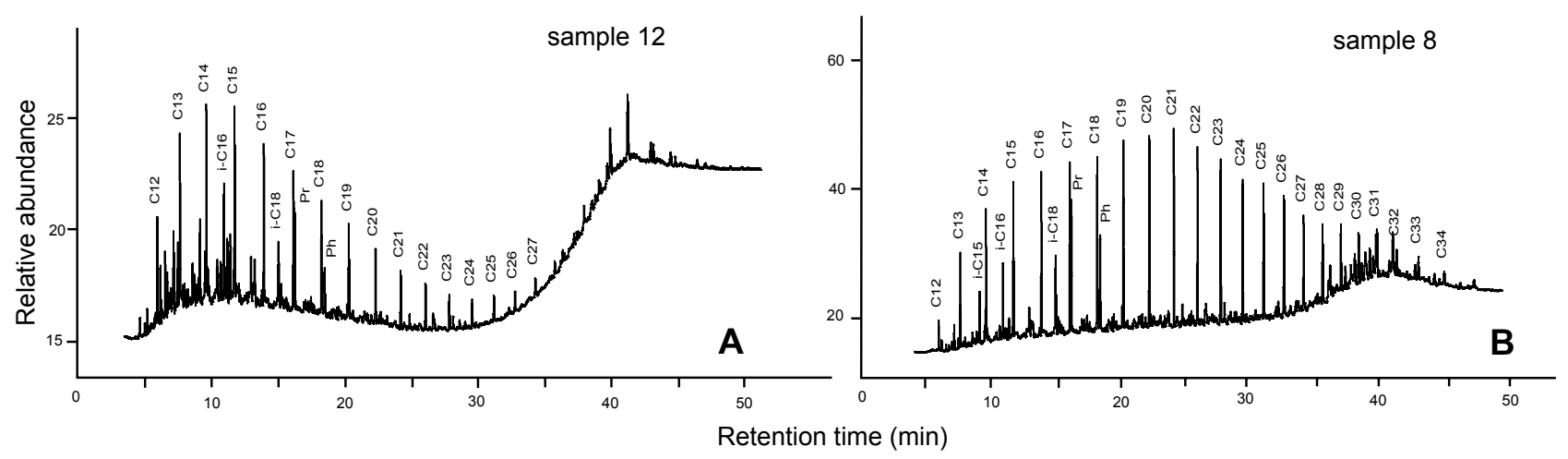

FIGURE 6. Chromatograms showing distribution of $n$-alkanes and acyclic isoprenoids of the aliphatic hydrocarbon fractions in the extracts from samples with: $A$ ) high $\mathrm{C}_{\text {org }}$ content; $\mathrm{B}$ ) low $\mathrm{C}_{\text {org }}$ content (see further explanation in the main text).

of the food chains (Ward and McCann, 2017) and following decreasing of differences between $\delta^{13} \mathrm{C}_{\text {org-con }}$ and $\delta^{13} \mathrm{C}_{\text {org }}$.

\section{DISCUSSION}

\section{Sedimentary model and paleoenvironments}

The studied Frasnian(Upper Devonian) Pymvashor River section is composed mainly of thin dark-grey mudstone, wackestone, and packstone beds, bearing tentaculites and/ or radiolarians, and black shales with high organic carbon content $\left(\mathrm{C}_{\text {org }}\right.$ as much as $22 \%$, average $\left.4.33 \%\right)$. Rock composition displays a rhythmical alternation of marlcarbonate-dominated beds, with minor occurrence of chert beds (Einsele, 1982; Einsele and Ricken, 1991). These rhythms may reflect variations in productivity, dilution of one component by another (e.g. carbonate/siliciclastic mud/organic matter/silica), and/or dissolution (Einsele, 1982). The studied succession is thought to be the result of cyclical changes in the accumulation rates of carbonate and chert, which do not coincide in phase because of changing supplies of clay and organic matter. Thus, the Pymvashor River succession preserves very probably a record of productivity cycles, that might be linked to periodic paleoclimate and/or paleoceanographic changes (Einsele

TABLE 3. Molecular organic geochemistry data of the aliphatic fractions

\begin{tabular}{|c|c|c|c|c|c|c|}
\hline Sample & 4 & 8 & 13 & 7 & 9 & 12 \\
\hline Lithology & chert & limestone & limestone & shale & shale & shale \\
\hline \multicolumn{7}{|c|}{$n$-Alkanes and isoprenoids } \\
\hline $\mathrm{Pr} / \mathrm{Ph}$ & 1.10 & 1.28 & 1.73 & 1.91 & 1.52 & 1.91 \\
\hline $\mathrm{Pr} / \mathrm{n}-\mathrm{C}_{17}$ & 0.84 & 0.93 & 0.96 & 0.45 & 1.03 & 0.82 \\
\hline $\mathrm{Ph} / n-\mathrm{C}_{18}$ & 0.80 & 0.73 & 0.67 & 0.32 & 0.78 & 0.55 \\
\hline \multicolumn{7}{|c|}{ Steranes } \\
\hline$\alpha \beta \beta \mathrm{C}_{27}, \%$ & 33 & 33 & 30 & 31 & 34 & 30 \\
\hline$\alpha \beta \beta C_{28}, \%$ & 16 & 17 & 14 & 17 & 18 & 15 \\
\hline$\alpha \beta \beta C_{29}, \%$ & 50 & 50 & 56 & 52 & 49 & 54 \\
\hline$\alpha \beta \beta C_{27} / \alpha \beta \beta C_{29}$ & 0.66 & 0.66 & 0.54 & 0.59 & 0.69 & 0.55 \\
\hline $\mathrm{C}_{27}$ Dia/Reg & 0.6 & 0.4 & 0.7 & 0.3 & 0.3 & 0.4 \\
\hline $\mathrm{C}_{29} 20 \mathrm{~S} / 20 \mathrm{~S}+\mathrm{R}$ & 0.45 & 0.47 & 0.47 & 0.43 & 0.45 & 0.45 \\
\hline $\mathrm{C}_{29} \alpha \beta \beta / \alpha \beta \beta+\alpha \alpha \alpha$ & 0.55 & 0.56 & 0.57 & 0.52 & 0.53 & 0.53 \\
\hline \multicolumn{7}{|c|}{ Terpanes } \\
\hline $\mathrm{C}_{24} / \mathrm{C}_{23}$ & 0.70 & 0.72 & 0.59 & 0.85 & 0.94 & 0.68 \\
\hline $\mathrm{C}_{29} / \mathrm{C}_{30}$ & 0.64 & 0.75 & 0.69 & 0.69 & 0.65 & 0.65 \\
\hline $\mathrm{C}_{35} \mathrm{~S} / \mathrm{C}_{34} \mathrm{~S}$ & 0.63 & 0.83 & 0.81 & 0.73 & 0.71 & 0.79 \\
\hline $\mathrm{C}_{32} 22 \mathrm{~S} / 22 \mathrm{~S}+\mathrm{R}$ & 0.62 & 0.59 & 0.59 & 0.59 & 0.59 & 0.60 \\
\hline $\mathrm{Ts} / \mathrm{Tm}$ & 0.84 & 0.46 & 0.74 & 0.48 & 0.31 & 0.54 \\
\hline sterane $/ 17 \alpha(\mathrm{H})$-hopane & 0.24 & 0.26 & 0.36 & 0.11 & 0.09 & 0.15 \\
\hline
\end{tabular}

$\mathrm{C}_{27}$ Dia/Reg: $\mathrm{C}_{27} \alpha \beta \alpha 20 \mathrm{~S}+20 \mathrm{R}$ diasteranes/ $\mathrm{C}_{27} \alpha \beta \beta$ 20S+20R regular steranes

Ts/Tm: $\mathrm{C}_{27} 17 \alpha(\mathrm{H})$-trisnorhopane/C ${ }_{27} 18 \alpha(\mathrm{H})$-trisnorneohopane 

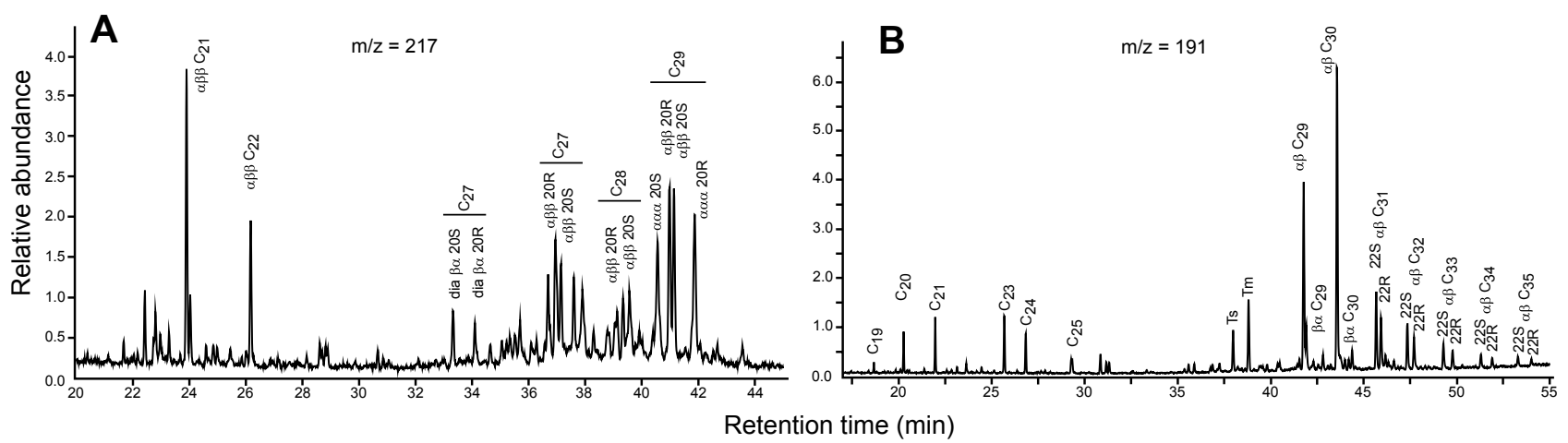

FIGURE 7. Mass chromatograms showing distributions of: A) steranes ( $\mathrm{m} / \mathrm{z} 217)$; B) terpanes $(\mathrm{m} / \mathrm{z} 191)$ of the aliphatic hydrocarbon fractions (sample 12) (see further explanation in the main text).

and Ricken, 1991). Compositional aspects of the succession described earlier suggest that the main components of productivity were biogenic and biochemogenic carbonates (mainly tentaculites and green algae) and biogenic silica (radiolarians and sponge spicules). Settling of suspended particles, including dead plankton, pellets, and mineral particles from the photic zone, provided the main volume of carbonate mud (micrite), biogenic silica (chert), and accumulations of shells and detritus deposited.

The finely-crystalline matrix, the laminar texture, and dominance of pelagic fossils (tentaculitids and radiolarians) in the studied facies indicate a deep water, low energy depositional regime, below the storm wave base. The presence of tentaculites in the limestones (packstone-grainstone; Fig. 4B) and the gradational character of their distribution in the sediment suggest of deposition from lateral suspension flows. Such deposits in the deep water basin could be related to erosion and re-deposition of shallow-water sediments during storm surges that resulted in granular flows (tempestites). Similar deposits are described from Middle PleistoceneHolocene sediments on the northern slope of the Little Bahama Bank (Lantzsch et al., 2007). Thus, the studied Early-Middle Frasnian interval consists of rhythmically intercalated thinly bedded limestone and shale deposited in deep water by episodic carbonate influx from the shallow-water platform induced by storms. Periodicity of the storms could be mediated by short-term climate changes accompanying the Middle Frasnian cooling (Pisarzowska et al., 2020). Increasing latitudinal temperature gradients probably provoked increasing in tropical storm frequency and vice versa. Beds 3, 7 and 10 dominated by organic-rich laminated shales are considered to represent episodes of low climatic gradient. Predominance of pelagic cherts and shales in the bed 3 suggests correspondence of this bed to the radiolarian bloom associated with the Middlesex Event.

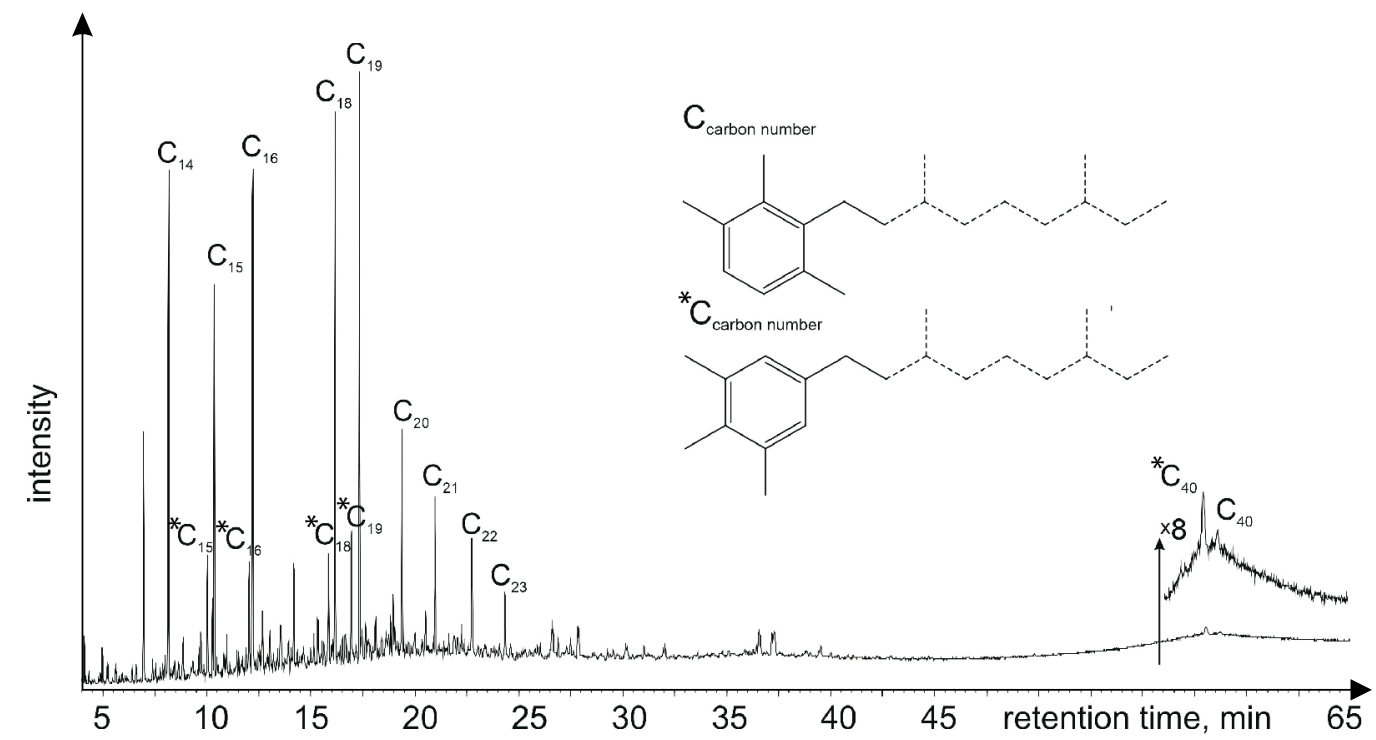

FIGURE 8. Summed mass-chromatogram $\mathrm{m} / \mathrm{z} 133+134$ of an aromatic fraction (sample 9 ). ${ }^{*} \mathrm{C}_{40}$ is paleorenieratane, $\mathrm{C}_{40}$ is isorenieratane (see further explanation in the main text). 


\section{Composition of organic matter and depositional environments}

The predominance of $n$-alkanes in the range below $n-\mathrm{C}_{20}$ and $\mathrm{Pr} / n-\mathrm{C}_{17}$ less than 1 reflects a dominantly marine algal source of organic matter (Tissot and Welte, 1984). Pristane $(\mathrm{Pr})$ to phytane $(\mathrm{Ph})$ ratios of the studied sample are generally greater than $1.0(1.10-1.91$, Table 3$)$, typical of the range generally considered to describe a normal marine environment (Didyk et al., 1978). This, relatively high $\mathrm{Pr} / \mathrm{Ph}$ values are accompanying with isorenieratene derivatives presents. The same situation was early reported for the Domanik Formation of the Timan-Pechora Basin (Bushnev et al., 2017b). $\mathrm{Pr} / \mathrm{Ph}$ values ranging from 1 to 2 in combination with paleorenieratene and isorenieratene derivatives were recently reported (Connock et al., 2018), where some possible causes were discussed: thermal maturity, heterogeneous pristane and phytane source, pristane coelution, phytane structure binding into sulphur compounds as well as relatively short euxinic events during deposition. Thus, we assume other pristane source in Domanik Formation of the Timan-Pechora Basin and short time episodic euxinic events.

The sterane distribution of the Pymvashor River sample suite $\left(\mathrm{C}_{27}-\mathrm{C}_{29}\right.$, Table 3$)$ is typical of planktonic and algal sources of organic matter. Whereas the main source of $\mathrm{C}_{27}$ steranes is marine phytoplankton, $\mathrm{C}_{29}$ steranes are typically associated with land plants (Huang and Meinschein, 1979; Waples and Michihara, 1991). However comparatively higher contribution of $\mathrm{C}_{29}$ to $\mathrm{C}_{27}$ steranes has been observed in marine Paleozoic sediments (Moldowan et al., 1985; Romero and Philp, 2012; Volkman, 1986) of different locations and also in previous studies of this basin (Bazhenova et al., 2008; Bushnev et al., 2017a, b) making unnecessary the terrestrial input to explain sterane distribution. This is compatible with the deposition in a relatively deep shelfal water environment as reported by Belyaeva et al. (1998).

The $\mathrm{C}_{29} / \mathrm{C}_{30}$ and $\mathrm{C}_{35} \mathrm{~S} / \mathrm{C}_{34} \mathrm{~S}$ hopane ratios are used in tandem to elucidate depositional environments and redox conditions (Peters et al., 2005). The obtained $\mathrm{C}_{29} / \mathrm{C}_{30}$ values of 0.64-0.75 and $\mathrm{C}_{35} \mathrm{~S} / \mathrm{C}_{34} \mathrm{~S}$ values of $0.63-0.83$ (Table 3) are typical of oxygen-depleted depositional environments. The sterane/17 $\alpha(\mathrm{H})$-hopane ratio is commonly used as an indicator of the proportion of bacterial biomass (prokaryotes) relative to that of eukaryotes (Peters and Moldowan, 1991; Waples and Michihara, 1991). The lowest values of this ratio were observed in shale samples (Table 3 ), suggesting a greater contribution of prokaryotes to the organic matter of these samples.

The presence of isorenieratene derivatives is confirmed in the aromatic fraction of the analysed bitumen extracts.
Isorenieratene is a biomarker of green sulphur bacteria (Chlorobiacea), indicating photic zone anoxia (Hartgers et al., 1994; Koopmans et al., 1996). Previous studies of the Domanik Formation in the Chut' and Shar'yu river sections (Bushnev et al., 2016) have revealed that aryl carotenoids derivatives are characterised by the presence of carbon enriched with the heavy isotope, a reliable sign of the connection of these compounds with organic matter of sulphur bacteria of the genus Chlorobium (van der Meer et al., 1998). Therefore, the accumulation and preservation of organic matter in sediments of the studied section was probably favored by anoxic conditions. The presence of isorenieratene derivatives, an indicator of photic zone anoxia, has been described from Late Devonian strata in other Laurussian carbonate shelf regions (Hartgers et al., 1994; Marynowski et al., 2008; Poludetkina et al., 2017; Racka et al., 2010). Poludetkina et al. (2017) noted that variable concentrations of isorenieratene derivatives tell of the changing intensity of anoxia. Differences of the aryl carotenoid derivatives in bitumen among samples of the Pymvashor River section likely reflect changes in the degree of anoxia in the paleobasin.

Bushnev et al. (2016) suggested that the prevalence of anoxia in deep water shelf depressions of the TimanPechora Basin during Middle Frasnian time resulted from the establishment of a thermocline, the formation of which has been attributed to upwelling near the shelf margin. Similar paleohydrographic conditions of weak vertical circulation have been reported from the North American cratonic basin, where black shale of Middle Devonian to Early Carboniferous age accumulated (Algeo et al., 2007). Oxygen depletion in the water column of a semi-isolated deep-water depression may be triggered by local phytoplankton blooms induced by increased nutrient delivery from the continent and/or ocean.

\section{Carbon isotope record}

The screened carbonate carbon isotope record of the Pymvashor River section shows a major positive excursion (major event III of Pisarzowska et al., 2006) separated by a negative shift near the boundary between the MN 5 and MN 6 conodont zones (Figs. 3; 9). The similarity of the $\delta^{13} \mathrm{C}$ profiles of the studied succession with the isotope signatures documented from south and central Laurussia and China suggests that perturbations of the carbon cycle during the punctata Zone time were global (Ma et al., 2008; Morrow et al., 2009; Pisarzowska et al., 2006, 2020; Yans et al., 2007). The close similarity of the Cis-Uralian and Chinese $\delta^{3} \mathrm{C}_{\text {carb }}$ oscillations, including the two-step pattern of major positive excursions (Ma et al., 2008), suggest a robust correlation potential of the entire punctata Event as well as lesser intra-event excursions. Similar $\delta^{13} \mathrm{C}$ variations have been reported from the Frasnian sequence 
of the Main Devonian Field (biogenic calcite of brachiopod shells; shallow-water facies) of the East European Platform (Zhuravlev et al., 2006), from the Kostomłoty-Mogiłki section (hemipelagic facies; bulk carbonates) in the Holy Cross Mountains (see Pisarzowska et al., 2006: fig. 10), and from the sections of Miette Carbonate Platform, Western Canada basin (Śliwiński et al., 2011).

Lower amplitudes of $\delta^{13} \mathrm{C}_{\text {carb }}$ shifts in the punctata Zone in the Cis-Uralian realm $(<3 \%$ o $)$ contrast with prominent excursions in south Laurussian and Chinese successions (>4\%o) (Fig. 9). Such magnitude differences may reflect diagenetic depletion of $\delta^{13} \mathrm{C}_{\text {carb }}$ values due to high $\mathrm{C}_{\text {org }}$ content and/or specific local environmental conditions (e.g. decreased burial rate of marine organic matter, variable freshwater delivery to the basin). Screening of the raw isotope data used in this study suggests low-significance effects of diagenetic alterations.

The organic carbon isotope pattern of the Pymvashor River section shows three positive-to-negative excursions spanning the punctata conodont Zone (Figs. 3; 9). The amplitude of $\delta^{13} \mathrm{C}_{\mathrm{org}}$ variations and maximum values decrease upward from $2.5 \%$ to $1.4 \%$ and from $-27 \%$ o to $-28.9 \%$, respectively. Magnitude of variations and values of $\delta^{13} \mathrm{C}_{\text {org }}$ in the Pymvashor River section are less than those observed in the North American, Polish, and Chinese sections (Lash, 2019; Ma et al., 2008; Morrow et al., 2009), perhaps a function of differences in $\mathrm{pCO}_{2}$ in sea water of these basins (Rau et al., 1989) and/or local variations in plankton structure (e.g. predominance of phytoplankton in eutrophic conditions can elevate the proportion of ${ }^{12} \mathrm{C}$ in $\mathrm{C}_{\text {org }}$ ). For example, regional elevation of $\mathrm{pCO}_{2}$ in sea water of the Timan-Pechora Basin at Middle-Frasnian may be caused by synchronous alkaline ultramafic magmatism in the Kola large igneous province (Wu et al., 2013).

The Cis-Uralian $\delta^{13} \mathrm{C}_{\text {org }}$ data from conodont elements $\left(\delta^{13} \mathrm{C}_{\text {org-con }}\right)$ shows a minor negative excursion near the base of the punctata conodont Zone and a positive shift in the lower part of the zone (Fig. 9). The $\delta^{13} \mathrm{C}_{\text {org-con }}$ pattern probably reflects changes in the pelagic trophic web and variations of $\delta^{13} \mathrm{C}_{\mathrm{org}}$ at basal trophic levels. It is likely that a

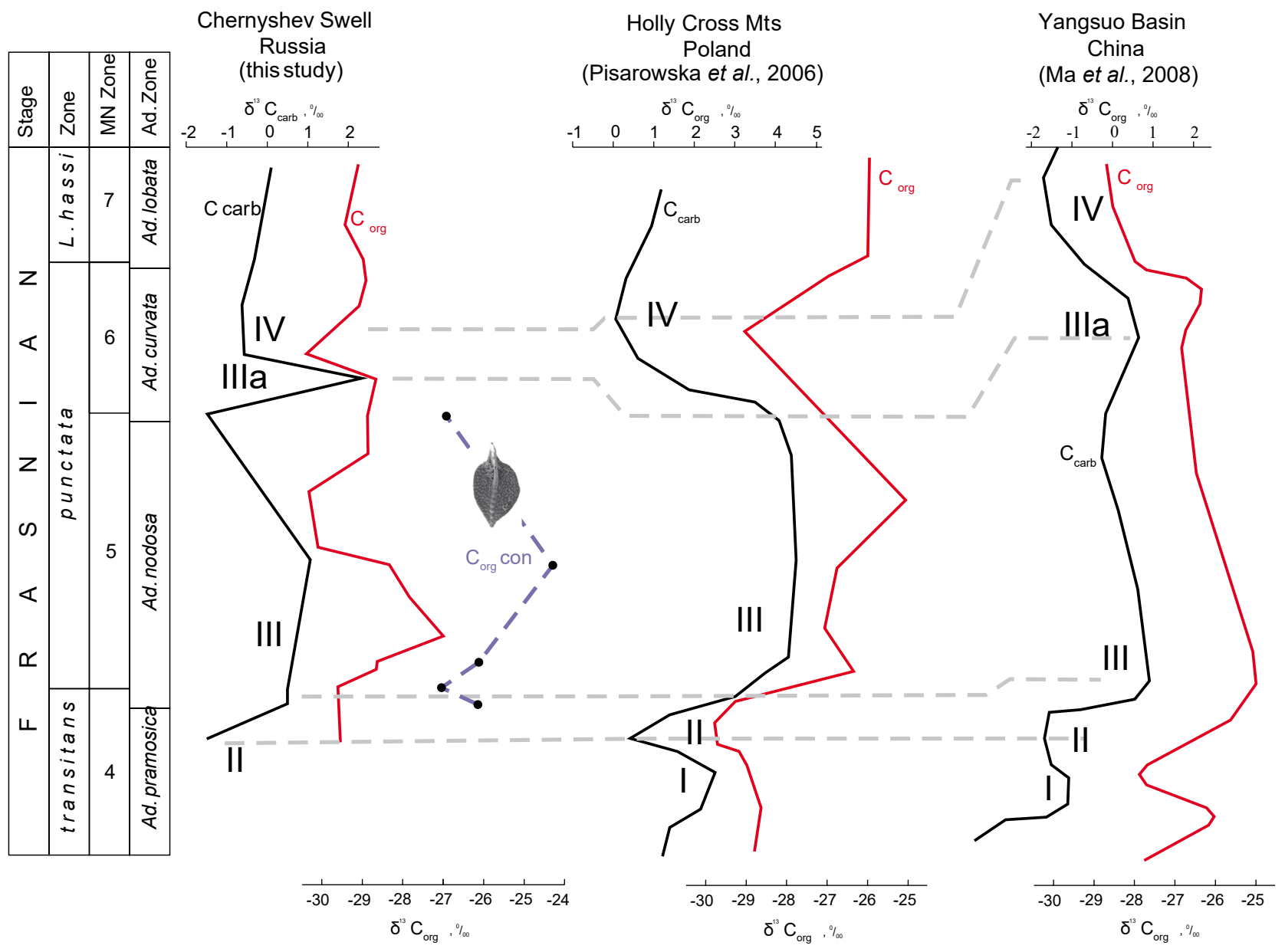

FIGURE 9. Inorganic and organic carbon isotope record of the Early-Middle Frasnian transition in the Cis-Urals (this study), Poland (Pisarowska et al., 2006) and China (Ma et al., 2008). Labels I, II, III, IIla, and IV designate the carbon isotopic events distinguished by Pisarzowska et al. (2006) and this study. Ad. Zone - conodont zonation based on Ancyrodella according to Pisarzowska et al. (2020). 
negative shift of $\delta^{13} \mathrm{C}_{\text {org-con }}$ corresponds to an increase of the ${ }^{13} \mathrm{C}$-depleted phytoplankton portion in the conodont diet, and a positive shift relates to an increase of the ${ }^{13} \mathrm{C}$-enriched zooplankton portion in the conodont diet.

\section{CONCLUSIONS}

The Early-Middle Frasnian succession in the Pymvashor River section in the north-eastern of the Timan-Pechora Basin (North Cis-Urals), consist of rhythmically interbedded thin limestone and shale beds (and a minor chert bed) deposited in a deep water environment, where the sedimentation of siliciclastic mud and organic matter was occasionally interrupted by storm sediment contribution from the adjacent shallower carbonate platform. The absence of bioturbation and benthic organisms in the organic-rich black shales indicates an oxygen-depleted depositional environment. Moreover, the detection of isorenieratene derivatives in the organic matter suggests anoxic conditions throughout the water column. The sedimentological characteristics and inferred redox conditions that accompanied the accumulation of organic matter are similar to that of the coeval deposits of the Holy Cross Mountains in Poland (Marynowski et al., 2008; Pisarzowska et al., 2006).

The Pymvashor River section preserves a robust record of the Early-Middle Frasnian carbon isotope Event in the carbonates and organic matter. The close similarity of the Cis-Uralian and Chinese $\delta^{13} \mathrm{C}_{\text {carb }}$ records, including the twostep pattern of a major positive excursion, suggests a strong potential for long distance stratigraphic correlation of the punctata Event and the minor intra-event positive excursions. A similar event pattern has also been documented from the Kostomłoty-Mogiłki section in the Holy Cross Mountains. Magnitude of variations and values of $\delta^{13} \mathrm{C}_{\text {org }}$ and $\delta^{13} \mathrm{C}_{\text {carb }}$ in the punctata Zone in the Pymvashor River section are less than those observed in the North American, Polish, and Chinese successions. Such differences may reflect local/ regional paleoenvironmental variability.

\section{ACKNOWLEDGMENTS}

The research was supported by projects AAAA-A17-117121270033-6 and AAAA-A17-117121140081-7 of the Institute of Geology Komi SC UB RAS. Much appreciation is due to Lluís Cabrera, Gary Lash, Angeles Borrego and the anonymous reviewers for their efforts to improve the manuscript.

\section{REFERENCES}

Algeo, T.J., Lyons, T.W., Blakey, R.C., Over, D.J., 2007. Hydrographic conditions of the Devono-Carboniferous
North American Seaway inferred from sedimentary MoTOC relationships. Palaeogeography, Palaeoclimatology, Palaeoecology, 256, 204-230.

Bai, S.L., Bai, Z.Q., Ma, X.P., Wang, D.R., Sun, Y.L., 1994. Devonian Events and Biostratigraphy of South China. Beijing, Peking University Press, 303pp.

Baliński, A., 2006. Brachiopods and their response to the EarlyMiddle Frasnian biogeochemical perturbations on the South Polish carbonate shelf. Acta Palaeontologica Polonica, 51(4), 647-678.

Bazhenova, T.K., Shimanskiy, V.K., Vasil'yeva, V.F., Shapiro, A.I., Yakovleva (Gembitskaya), L.A., Klimova, L.I., 2008. Organic geochemistry of the Timan-Pechora basin (in Russian). Saint-Petersburg, All-Russia Petroleum Research Exploration Institute, 164pp.

Becker, R.T., House, M.R., Kirchgasser, W.T., 1993. Devonian goniatite biostratigraphy and timing of facies movements in the Frasnian of the Canning Basin, Western Australia. Geological Society Special Publication (London), 70, 293321.

Belonin, M.D., Prischepa, O.M., Teplov, E.L., Budanov, G.F., Danilevskiy, S.A., 2004. The Timan-Pechora province: geological structure, petroleum potential and prospects of development (in Russian). Saint-Petersburg, Nedra, 396pp.

Belyaeva, N.V., Korzun, A.L., Petrova, L.V., 1998. The model of sedimentation of the Frasnian-Tournaisian deposits in the north-east of European Platform (in Russian). SaintPetersburg, Nauka, 154pp.

Belyaeva, N.V., Ivanov, A.O. (eds.), 2000. South Timan Field Trip Guidebook July 6-11, 2000. Supplement to Special Publication of Ichthyolith Issues 6. Published by Institute of Geology, Komi Science Centre, Uralian Division, Russian Academy of Sciences, 84pp.

Brand, U., Logan, A., Bitner, M.A., Griesshaber, E., Azmy, K., Buhl, D., 2011. What is the ideal proxy for Palaeozoic seawater chemistry? Memoirs of the Association of Australasian Palaeontologists, 41, 9-24.

Bushnev, D.A., Burdel'naya, N.S., Ponomarenko, E.S., Zubova, T.A. (Kiryukhina), 2016. Anoxia in the Domanik basin of the Timan-Pechora region. Lithology and Mineral Resources, 51(4), 283-289.

Bushnev, D.A., Burdel'naya, N.S., Valyayeva, O.V., Derevesnikova, A.A., 2017a. Geochemistry of Late Devonian oils of the Timan-Pechora basin. Russian Geology and Geophysics, 58 (3-4), 332-342.

Bushnev, D.A., Burdel'naya, N.S., Zhuravlev, A.V., 2017b. Organic matter in Upper Devonian deposits of the Chernyshev Ridge. Geochemistry International, 55(6), 548-558.

Chen, J., Montañez, I.P., Qi, Y., Wang, X., Wang, Q., Lin, W., 2016. Coupled sedimentary and $\delta^{13} \mathrm{C}$ records of late Mississippian platform-to-slope successions from South China: Insight into $\delta^{13} \mathrm{C}$ chemostratigraphy. Palaeogeography, Palaeoclimatology, Palaeoecology, 448, 162-178.

Connock, G.T. Nguyen, T.X., Philp, R.P., 2018. The development and extent of photic-zone euxinia concomitant with Woodford 
Shale deposition. American Association of Petroleum Geologists Bulletin (AAPG), 102(6), 959-986.

Didyk, B.M., Simoneit, B.R.T., Brassell, S.C., Eglinton, G., 1978. Organic geochemical indicators of palaeoenvironmental conditions of sedimentation. Nature, 272, 216-222.

Einsele, G., 1982. Limestone-marl cycles (periodites): diagnosis, significance, causes - a review. In: Einsele, G., Seilacher, A. (eds.). Cyclic and Event Stratification. Berlin, Springer, 8-53.

Einsele, G., Ricken, W., 1991. Limestone-marl alternation - an overview. In: Einsele, G., Ricken, W., Seilacher, A. (eds.). Cycles and Events in Stratigraphy. Berlin, Springer, 23-47.

French, K.L., Rocher, D., Zumberge, J.E., Summons, R.E., 2015. Assessing the distribution of sedimentary $\mathrm{C}_{40}$ carotenoids through time. Geobiology, 13, 139-151.

Gruzdev, D.A., 2017. The Late Devonian-Early Carboniferous isolated carbonate platform in the Subpolar Urals (Bol'shaya Nadota River) (in Russian). Vestnik IG Komi SC UB RAS, 4(268), 16-23.

Hartgers, W.A., Sinninghe Damsté, J.S., Requejo, A.G., Allan, J., Hayes, J.M., Yue Ling, Tian-Min Xie, Primack, J., de Leeuw, J.W., 1994. A molecular and carbon isotopic study towards the origin and diagenetic fate of diaromatic carotenoids. Organic Geochemistry, 22 (3-5), 703-725.

Huang, W.Y., Meinschein, W.G., 1979. Sterols as ecological indicators. Geochimica et Cosmochimica Acta, 43, 739-745.

Huck, S., Wohlwend, S., Coimbra, R., Christ, N., Weissert, H., 2017. Disentangling shallow water bulk carbonate carbon isotope archives with evidence for multi stage diagenesis: An in depth component specific petrographic and geochemical study from Oman (Mid Cretaceous). The Depositional Record, 3(2), 233-257.

Immenhauser, A., Della Porta, G., Kenter, J.A.M., Bahamonde, J.R., 2003. An alternative model for positive shifts in shallow marine carbonate $\delta^{13} \mathrm{C}$ and $\delta^{18} \mathrm{O}$. Sedimentology, 50, 953-959.

Johnson, J.G., Klapper, G., Sandberg, C.A., 1985. Devonian eustatic fluctuations in Euroamerica. Geological Society of America Bulletin, 96, 567-587.

Kachmashev, V.V., Ptitsyn, M.B., Afanasyeva, T.A., Trukhacheva, N.A., Oberman, N.G., Derevyanko, I.V., 1988. Report of the Adzvinskaya Geological Survey Department for 1984-1988. Technical report (in Russian). Russia, Vorkuta, 260pp.

Koopmans, M.P., Koster, J., van Kaam-Peters, H.M.E., Kenig, F, Schouten, S., Hartgers, W.A., de Leeuw, J.W., Sinninghe Damste, J.S., 1996. Diagenetic and catagenetic products of isorenieratene: Molecular indicators for photic zone anoxia. Geochimica et Cosmochimica Acta, 60, 4467-4496.

Kotik, I.S., Valyaeva, O.V., Bushnev, D.A., Zhuravlev, A.V., 2019. Organic matter geochemistry of the Domanic section along the Pymvashor river, Chernyshev swell (Timan-Pechora Basin) (in Russian). Vestnik IG Komi SC UB RAS, 9, 10-16.

Kuzmin, A.V., Yatskov, S.V., Orlov, A.N., Ivanov, A.O., 1997. "Domanik Crisis" in the Evolution of Fauna of the Frasnian Marine Basin in the South Timan. Paleontological Journal, 31(3), 251-258.
Lantzsch, H., Roth, S., Reijmer, J.J.G., Kinkel, H., 2007. Sea-level related resedimentation processes on the northern slope of Little Bahama Bank (Middle Pleistocene to Holocene). Sedimentology, 54(6), 1307-1322.

Lash, G.G., 2019. A global biogeochemical perturbation during the Middle Frasnian punctata Event: evidence from muted carbon isotope signature in the Appalachian Basin, New York State (USA). Global and Planetary Change, 177, 239-254.

Lohmann, K.C., 1988. Geochemical patterns of meteoric diagenetic systems and their application to studies of paleokarst. In: James, N.P., Choquette, P.W. (eds.). Paleokarst. Berlin, Springer, 58-80.

Ma, X.-P., Becker, R.T., Li, H., Sun, Y.-Y., 2006. Early and Middle Frasnian brachiopod faunas and turnover on the South China shelf. Acta Palaeontologica Polonica, 51(4), 789-812.

Ma, X.-P., Wang, Ch.-Y., Racki, G., Racki, M., 2008. Facies and geochemistry across the Early-Middle Frasnian transition (Late Devonian) on South China carbonate shelf: Comparison with the Polish reference succession. Palaeogeography, Palaeoclimatology, Palaeoecology, 269, 130-151.

Marynowski, L., Filipiak, P., Pisarzowska, A., 2008. Organic geochemistry and palynofacies of the Early-Middle Frasnian transition (Late Devonian) of the Holy Cross Mts, southern Poland. Palaeogeography, Palaeoclimatology, Palaeoecology, 269, 152-165.

Moldowan, J.M., Seifert, W.K., Gallegos, E.J., 1985. Relationship between petroleum composition and depositional environment of petroleum source rocks. American Association of Petroleum Geologists (AAPG), 69 (Bulletin), 1255-1268.

Morrow, J.R., Sandberg, C.A., Malkowski, K., Joachimski, M.M., 2009. Carbon isotope chemostratigraphy and precise dating of middle Frasnian (lower Upper Devonian) Alamo Breccia, Nevada, USA. Palaeogeography, Palaeoclimatology, Palaeoecology, 282, 105-118.

Nikonov, N.I., Bogatskii, V.I., Martynov, A.V., Larionov, Z.V., Laskin, V.M., Galkona, L.V., Dovzhikova, E.G., Ermakova, O.L., Kostygova, P.K., Kuranova, T.I., Moskalenko, K.A., Pankratov, Yu.A., Petrenko, E.L., Popova, E.V., Surina, A.I., Shabanova, G.A., 2000. The Timan-Pechora Sedimentation Basin: Atlas of Geologic, Lithofacies, Structural and Paleogeographic maps (in Russian). Ukhta, Timan-Pechora Research Center, 64pp.

Parmusina, L.V., 2007. The Upper Devonian complex of the Timan-Pechora Province (structure, formation conditions, regularities of reservoir location and oil and gas potential) (in Russian). Saint-Petersburg, Nedra, 152pp.

Pershina, A.I., 1962. Silurian and Devonian deposits of the Chernyshev Swell (in Russian). Saint-Petersburg, Academy of Sciences of the Soviet Union, 122pp.

Peters, K.E., Moldowan, J.M., 1991. Effects of source, thermal maturity, and biodegradation on the distribution and isomerization of homohopanes in petroleum. Organic Geochemistry, 17, 47-61.

Peters, K.E., Walters, C.C., Moldowan, J.M., 2005. The biomarker guide. Volume 2: Biomarkers and isotopes in petroleum systems and Earth history. Cambridge, Cambridge University Press, 2nd edition, 1155pp. 
Pisarzowska, A., Sobstel, M., Racki, G., 2006. Conodont-based event stratigraphy of the Early-Middle Frasnian transition on the South Polish cabonate shelf. Acta Palaeontologica Polonica, 51, 609-646.

Pisarzowska, A., Becker, R.T., Aboussalam, Z.S., Szczerba, M., Sobień, K., Kremer, B., Owocki, K., Racki, G., 2020. Middlesex/punctata event in the Rhenish Basin (Padberg section, Sauerland, Germany) - Geochemical clues to the early-middle Frasnian perturbation of global carbon cycle. Global and Planetary Change, 191, 1-14.

Pisarzowska, A., Racki, G., 2012. Isotopic chemostratigraphy across the Early-Middle Frasnian transition (Late Devonian) on the South Polish carbonate shelf: A reference for the global punctata Event. Chemical Geology, 334, 199-220.

Poludetkina, E.N., Smirnov, M.B, Fadeeva, N.P., Kozlova, E.V., 2017. Proof of formation of organic matter in Upper Devonian carbonate and carbonate-siliceous sediments of the SouthTatar Uplift in constant photic layer anoxia. Geochemistry International, 55(8), 726-736.

Racka, M., Marynowski, L., Filipiak, P., Sobstel, M., Pisarzowska, A., Bond, D.P.J., 2010. Anoxic Annulata Events in the Late Famennian of the Holy Cross Mountains (Southern Poland): geochemical and paleontological record. Palaeogeography, Palaeoclimatology, Palaeoecology, 297, 549-575.

Racki, G., Joachimski, M.M., Morrow, J.R., 2008. A major perturbation of the global carbon budget in the EarlyMiddle Frasnian transition (Late Devonian). Palaeogeography, Palaeoclimatology, Palaeoecology, 269, 127-129.

Rau, G.H., Takahashi, T., Marais, D.J.D., 1989. Latitudinal variations in plankton $\delta^{13} \mathrm{C}$ : implications for $\mathrm{CO}_{2}$ and productivity in past oceans. Nature, 341(6242), 516-518.

Romero, A.M., Philp, R.P., 2012. Organic geochemistry of the Woodford Shale, Southeastern Oklahoma: How variable can shales be? American Association of Petroleum Geologists (AAPG), 96 (Bulletin), 493-517.

Scholle, P.A., Arthur, M.A., 1980. Carbon isotope fluctuations in Cretaceous pelagic limestones: Potential stratigraphic and petroleum exploration tool. American Association of Petroleum Geologists (AAPG), 64 (Bulletin), 67-87.

Śliwiński, M.G., Whalen, M.T., Newberry, R.J., Payne, J.H., Day, J.E., 2011. Stable isotope $\left(\delta^{13} \mathrm{C}_{\text {carb and org }}, \delta^{15} \mathrm{~N}_{\text {org }}\right)$ and trace element anomalies during the Late Devonian 'punctata Event' in the Western Canada Sedimentary Basin. Palaeogeography, Palaeoclimatology, Palaeoecology, 307, 245-271.

Soboleva, M.A., Sobolev, D.B., Matveeva, N.A., 2018. Frasnian section on the Kozhym River (the western slope of Polar Urals) - results of biostratigraphic, bio- and lithofacies, isotopic and geochemical studies (in Russian). Petroleum Geology - Theoretical and Applied Studies, 13(1). Last accessed: 21/03/2021. Website: http://www.ngtp.ru/rub/2/2_2018.pdf

Timonin, N.I., 1998. Pechora Plate: a history of geological evolution in the Phanerozoic (in Russian). Ekaterinburg, Ural Branch of the Russian Academy of Sciences, 240pp.
Tissot, B.P., Welte, D.H., 1984. Petroleum Formation and Occurrence, second edition. Berlin, Heidelberg, SpringerVerlag, 699pp.

Tsyganko, V.S., 2011. Devonian of the Western slope of the Northern Urals and Pay-Khoy (stratigraphy, separation principles, correlation) (in Russian). Ekaterinburg, Ural Branch of the Russian Academy of Sciences, 356pp.

van der Meer, M.T.J., Schouten, S., Sinninghe Damsté, J.S., 1998. The effect of the reversed tricarboxylic acid cycle on the ${ }^{13} \mathrm{C}$ contents of bacterial lipids. Organic Geochemistry, 27, 371397.

Volkman, J.K., 1986. A review of sterol markers for marine and terrigenous organic matter. Organic Geochemistry, 9, 83-99.

Waples, D.W., Machihara, T., 1991. Biomarkers for geologist - a practical guide to the application of steranes and triterpanes in petroleum geology. American Association of Petroleum Geologists (AAPG), Methods in Exploration, 71pp.

Ward, C.L., McCann, K.S., 2017. A mechanistic theory for aquatic food chain length. Nature Communications, 8, 2028.

Wu, F-Y., Arzamastsev, A.A., Mitchell, R.H., Li, Q.-L., Sun, J., Yang, Y.-H., Wang, R.-C., 2013. Emplacement age and Sr-Nd isotopic compositions of the Afrikanda alkaline ultramafic complex, Kola Peninsula, Russia. Chemical Geology, 353, 210-229.

Yans, J., Corfield, R.M., Racki, G., Preat, A., 2007. Evidence for perturbation of the carbon cycle in the Middle Frasnian punctata Zone (Late Devonian). Geological Magazine, 144(2), 263-270.

Yudin, V.V., 1994. Orogenesis of the North Urals and Pay-Khoy (in Russian). Ekaterinburg, Nauka, 284pp.

Zhuravlev, A.V., Sokiran, E.V., Evdokimova, I.O., Dorofeeva, L.A., Rusetskaya, G.A., Małkowski, K., 2006. Faunal and facies changes at the Early-Middle Frasnian boundary in the north-western East European Platform. Acta Palaeontologica Polonica, 51(4), 747-758.

Zhuravlev, A.V., Smoleva, I.V., 2018. Carbon isotope values in conodont elements from the latest Devonian-Early Carboniferous carbonate platform facies (Timan-Pechora Basin). Estonian Journal of Earth Sciences, 67(4), 238-246.

Zhuravlev, A.V., 2020. Thermal degradation of carbon isotope composition of conodont organic matter: preliminary results (in Russian). Vestnik of Geosciences, 2, 29-31.

Zhuravlev, A.V., Plotitsyn, A.N., Gruzdev, D.A., 2020. Carbon isotope ratios in the apatite-protein composites of conodont elements - palaeobiological proxy. In: Frank-Kamenetskaya, O.V., Vlasov, D.Y., Panova, E.G., Lessovaia, S.N. (eds.). Processes and Phenomena on the Boundary between Biogenic and Abiogenic Nature. Springer Nature Switzerland, 749-764.

Ziegler, W., Sandberg, C.A., 2001. Utility of palmatolepids and icriodontids in recognizing Upper Devonian series, stage, and possible substage boundaries.

Manuscript received June 2020;

revision accepted February 2021; published Online April 2021. 